\title{
Namtso Ancient Lagoon and Ancient Sea Erosion Landform
}

\author{
Yaohuang $\mathrm{Li}^{1}$ \\ ${ }^{1}$ Loudi City Geographic Information Center, Hunan, China
}

\begin{abstract}
During a certain geological period, the sea surface is at the current elevation of about 4746-4755 meters. When the sea surface is about 4746-4755 meters above sea level, the Namtso region of Tibet is a lagoon in the sea. The sea surface was kept stable at the above location for a long time, and a lot of sea erosion landforms were generated on the coast. The ancient sea erosion caves, sea erosion pillars, sea erosion arch bridges, sea erosion headlands, sea erosion headlands, sea erosion cliffs, sea erosion platforms and other various ancient sea erosion micro-landforms are well preserved on the banks of Namtso Lake. It is a unique and natural ancient coastal landscape park in the world
\end{abstract}

\section{Introduction:}

Namtso is the second largest lake in Tibet and the third largest saltwater lake in China. " Namtso " is Tibetan, and the Mongolian name is "Tengge Lihai", which means "Tianhu". The surface of Namtso Lake is 4718 meters above sea level, more than 70 kilometers long from east to west, more than 30 kilometers wide from north to south, and an area of about $1920 \mathrm{~km}^{2}$. The deepest part of Namco exceeds 120 meters, which is the largest lake in the world with the highest altitude. The author has been devoted to the study of ancient sea erosion landforms of the earth since 2004. In 2019, the author discovered the wellpreserved sea erosion landforms of the ancient geological period on the shore of Lake Namtso. The ancient sea erosion landforms in Namtso are rich in number, complete in variety, mature in development, and beautiful in shape. They are rare and precious resources for studying the history of land and sea changes in the Qinghai-Tibet Plateau and even the world.

\section{Ancient sea erosion landform on the shore of Namtso Lake}

\subsection{Ancient sea caves (cave) on the shore of Namtso Lake}

Sea erosion caves, also called wave erosion niches, are caves and grooves left by coastal bedrock eroded by sea waves.

Sea erosion cave is the most widely distributed sea erosion landform on the bedrock coast. Ancient sea caves are widely distributed on the cliffs and rock pillars of Namtso Lake..

\footnotetext{
${ }^{*}$ Corresponding author: 583574623@qq.com
}

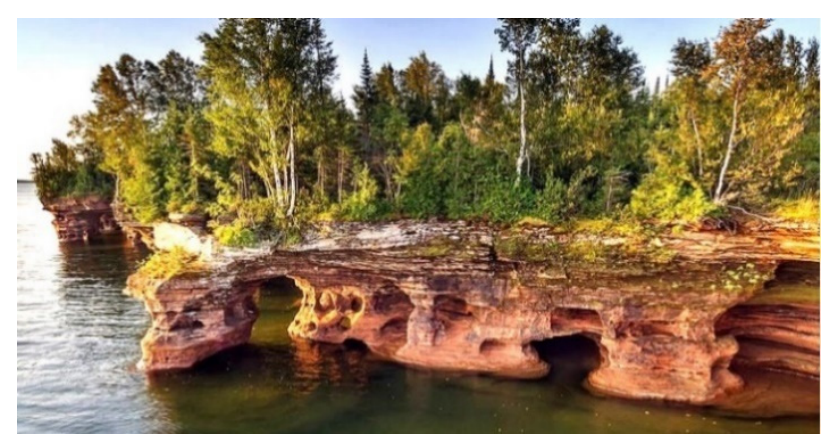

Figure 1A coast. There are abundant sea caves on the sea erosion cliffs on the coast..

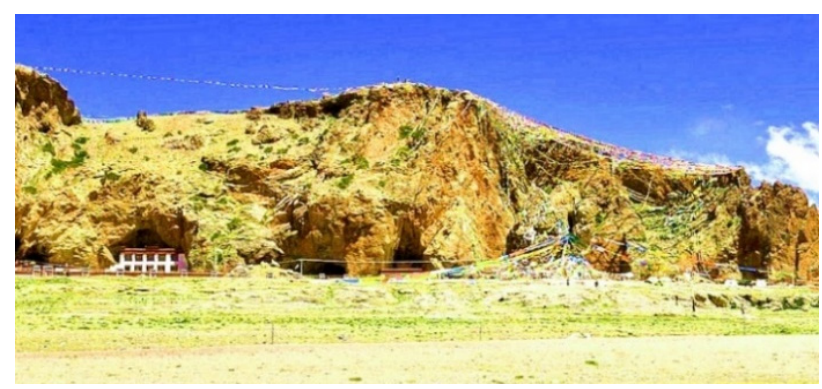

Figure 2 Ancient sea erosion cliffs on the ancient sea erosion platform on the west coast of Namtuzau Peninsula. Sea caves are distributed on the ancient sea cliffs

\subsection{Ancient sea erosion pillars by Namtso Lake}

A sea erosion column is a rock column formed by the collapse of the coast after being eroded by waves. Sea erosion pillars are usually distributed with sea erosion caves and horizontal ripples, which is a sign that distinguishes sea erosion pillars from non-sea erosion pillars.

There are a large number of ancient sea erosion columns in Namtso, such as Sansheng Stone, Husband Stone, Hezhang Stone, etc. 


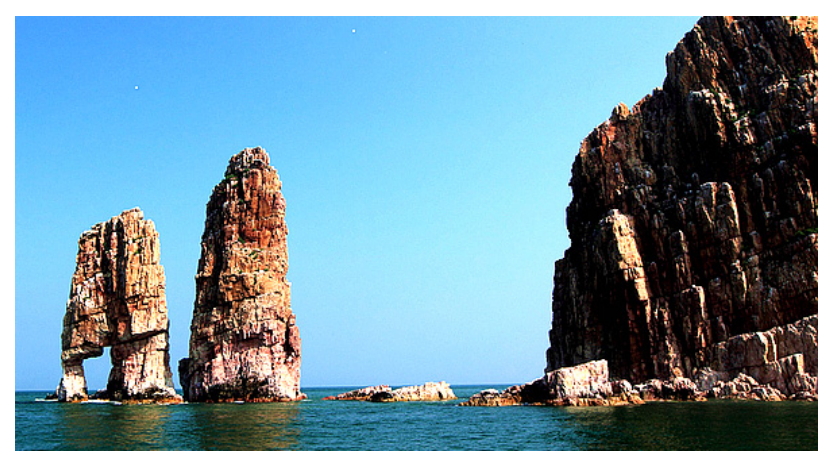

Figure 3.A sea erosion column

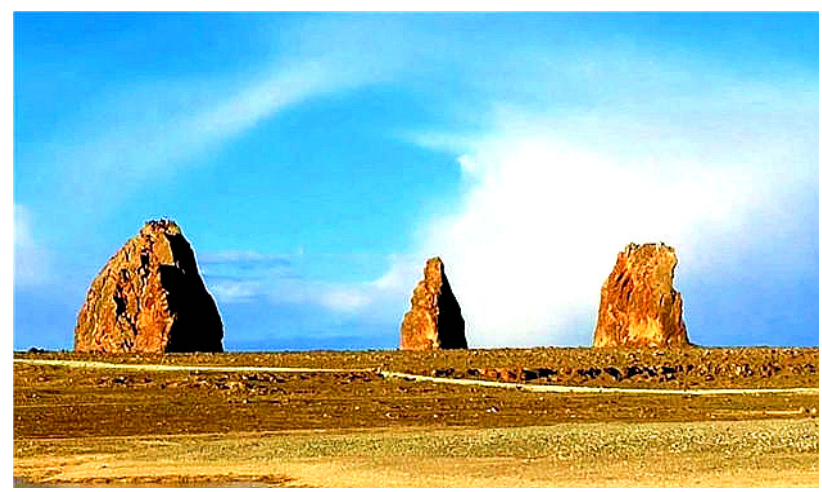

Figure 4 Sanshengshi of Namtso. Sanshengshi is an ancient sea eclipse group

\subsection{Ancient sea-eroded arch bridge in Namtso}

Sea erosion arch bridge, also known as land bridge or sea erosion arch, is a very rare and rare sea erosion landform on the bedrock coast.

Namtso has a very famous scenic spot called the Holy Elephant Tianmen. Shengxiang Tianmen is an ancient seaeroded arch bridge.

The reason why the sea erosion arch bridge is very rare is because its formation conditions are very strict and the formation process is very slow. The ancient sea erosion arch bridge is preserved in Namtso, indicating that the sea erosion has experienced a long geological process..

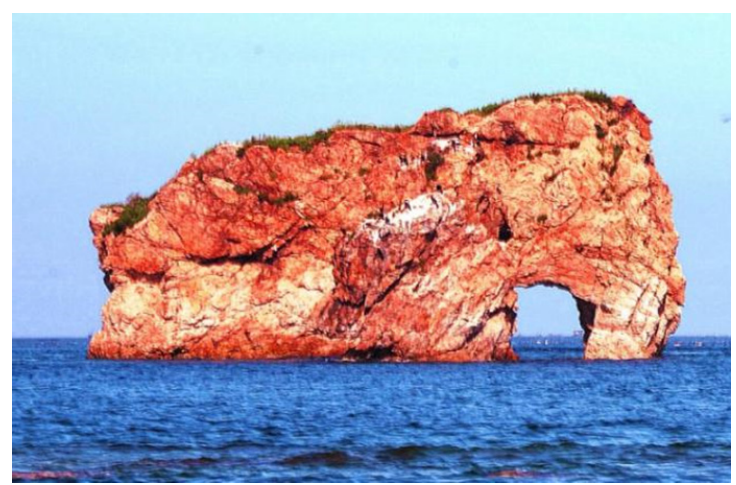

Figure 5 A sea erosion arch bridge

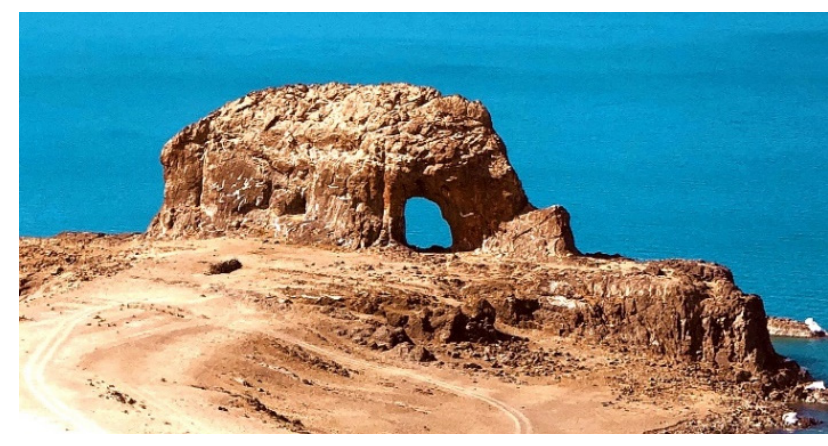

Figure 6 Namtuk Sacred Elephant Gate. Tianxiangmen is an ancient sea-eroded arch bridge

\subsection{Ancient sea erosion headland in Namtso}

The sea erosion headland refers to the sharp land formed by the sea erosion and protruding into the sea.

Sea erosion Cape Bay is a place formed by sea erosion and recessed into land.

The ancient sea erosion headland in Namtso is not only a large number, but also mature and mature, with a very beautiful shape. It is a rare specimen of ancient sea erosion landforms..

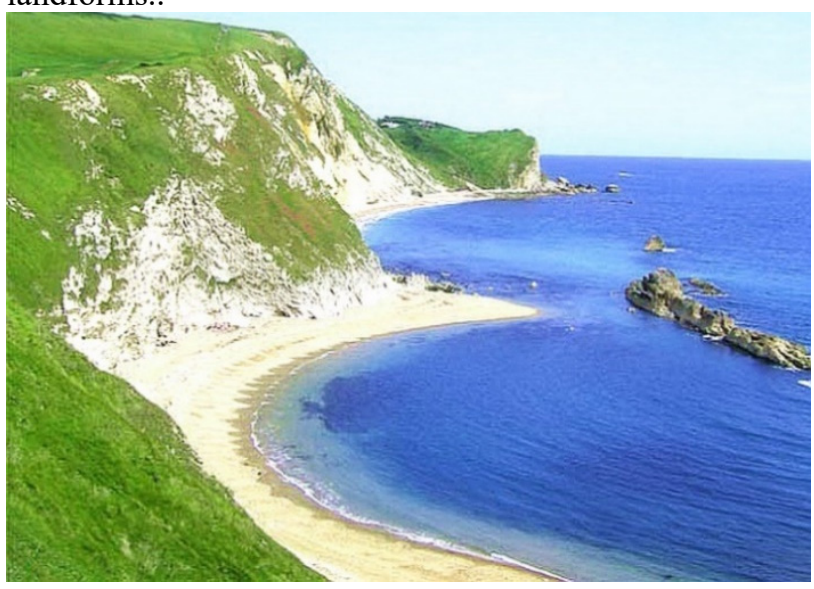

Figure 7 A sea erosion headland on the modern coast

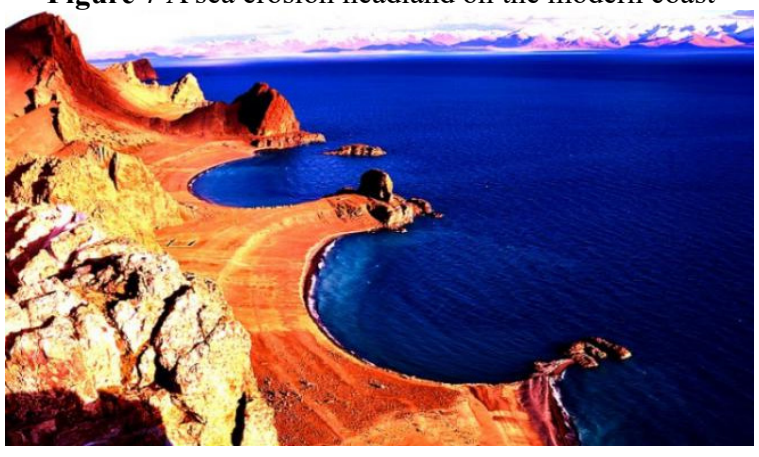

Figure 8 "Moon Bay" by Namtso Lake. Moon Bay is some ancient sea erosion

The scale of the ancient sea erosion headland in Namtso is not only rare in other regions, but even on the modern coast, it also proves that it has experienced a long sea erosion process. If a simple analogy is made, it can also be said that the time the sea surface is maintained at the current elevation of about 4745-4755 meters and the time the sea surface is maintained at the current location 
can be compared.

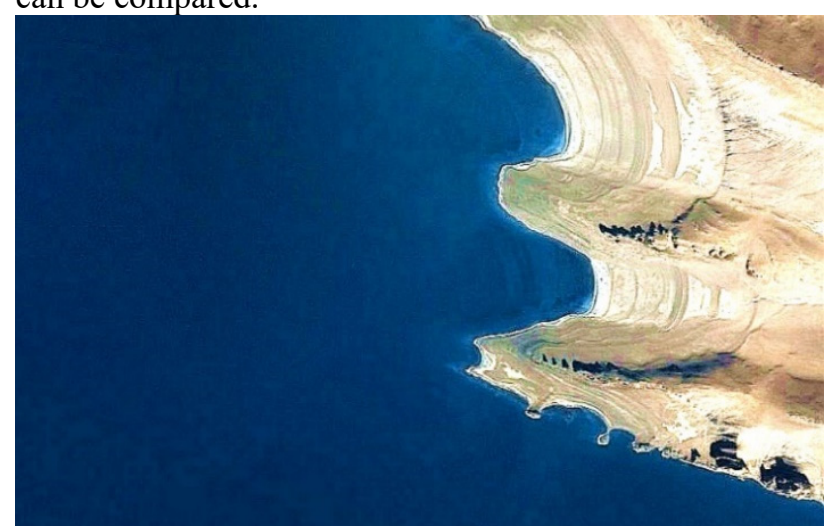

Figure 9 Ancient sea erosion headland headland on the shore of Namtso Lake

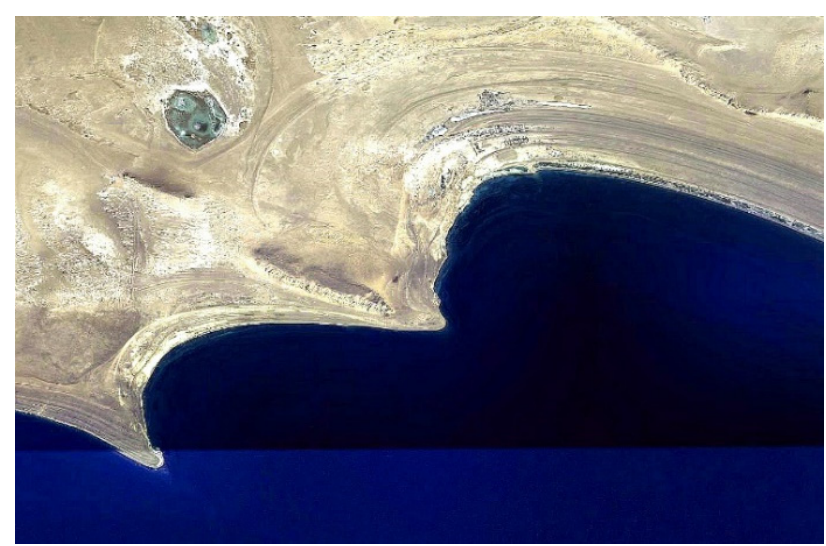

Figure 10 Ancient sea erosion headland headland on the shore of Namtso Lake

\subsection{Ancient sea erosion platform and ancient sea erosion cliff in Namtso}

The sea erosion cliff, also known as the wave erosion cliff, refers to the steep cliff wall formed by the coast collapsed after being eroded by the waves. A sea erosion platform refers to a flat bedrock platform formed in front of a sea erosion cliff.

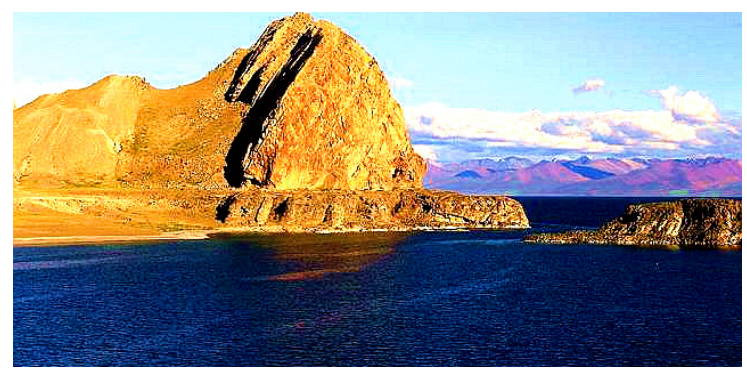

Figure 11 An ancient sea erosion platform and ancient sea erosion cliff on the shore of Namtso Lake

Numerous ancient sea erosion platforms and ancient sea erosion cliffs are distributed on the shore of Namtso Lake, especially the north shore.

\section{The location of the sea surface during the formation of the ancient sea erosion landforms in Namtso}

In theory, any kind of ancient sea erosion landform can indicate the location of the sea surface during its formation, and this is also the case. Numerous ancient sea erosion landforms in Namtso are sufficient to illustrate the seawater surface that existed during its formation period, and they can mutually support each other's true identity of sea erosion landforms, and are not considered wind erosion or lake erosion landforms.

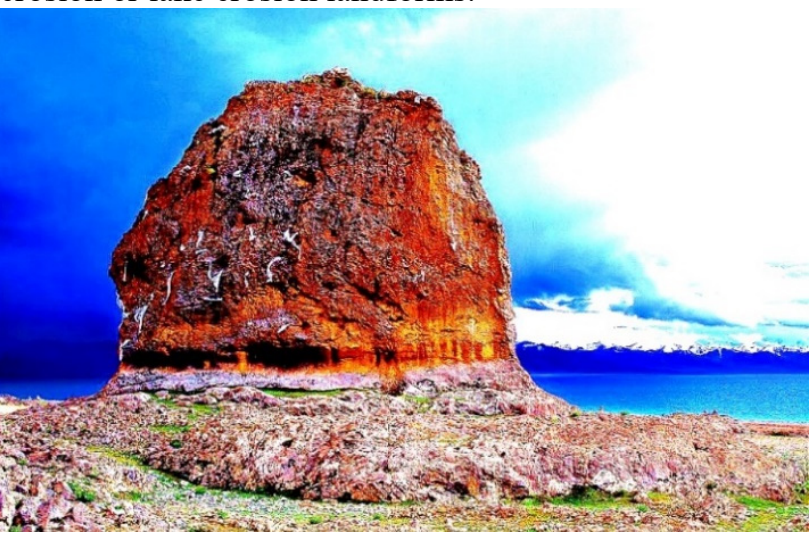

Figure 12 Ancient sea erosion pillars by Namtso Lake. The deepest part of the ancient sea erosion column Shanghai erosion is about the location of the high tide surface of the sea at that time

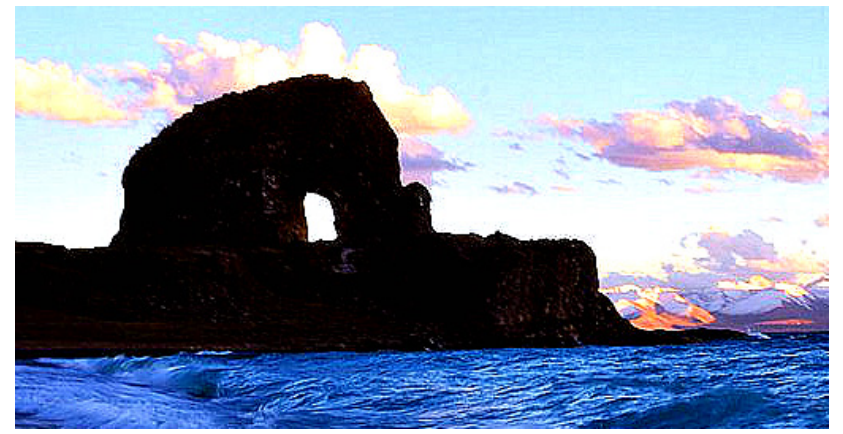

Figure 13 The ancient sea erosion arch bridge and ancient sea erosion platform in Namtso. The location intuitively reflects the positional relationship between the ancient sea surface and the current lake surface

By consulting various measurement data and judging from the topographic maps, during the formation period of the Namtso ancient sea landform described in this article, the sea surface of the Namtso area was approximately between 4746 and 4755 meters from the current sea level.

\section{Namtso Ancient Lagoon}

According to the analysis of the topography of the northern Tibetan plateau, during the formation of the Namtso ancient sea landform, the Namtso region was a lagoon. At that time, the Namtso ancient lagoon only had a width of less than 2 kilometers east of Xianquna. The lagoon mouth less than 20 meters deep is connected with the ocean. 


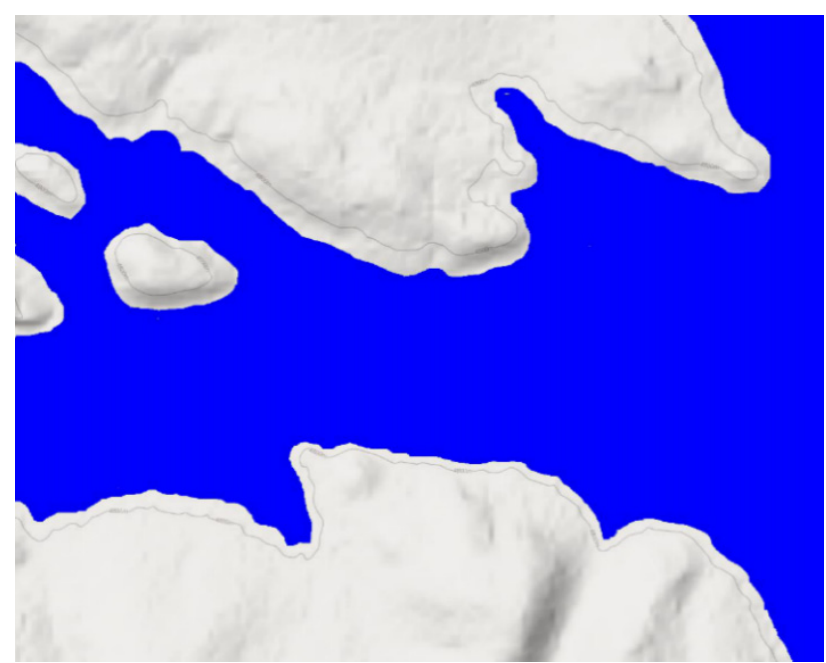

Figure 14 Namtso is a schematic diagram of the lagoon mouth during the ancient lagoon period iver

When the sea surface is approximately between 4746 meters and 4755 meters in the current sea, the northern Tibetan plateau is a shallow sea basin between high mountains, and the Namco Coo Lagoon's waterway leading to the open sea is tortuous and long. Lincuo, Bamcuo, Pengcuo, Cuohu, and the Naqu and Nujiang waterways are only connected to the open sea.

It is precisely because the sea surface is located at a position of about 4746 meters to 4755 meters in the current sea, Namco is a lagoon connected with the sea, and the above-mentioned ancient sea erosion landforms of Namtso can confirm the identity of the sea erosion landforms. However, on the other hand, landforms formed by factors such as lake erosion, wind erosion, and ice erosion cannot reach the scale of sea erosion landforms and have the characteristics of sea erosion landforms. In other words, no matter where they appear, the above landforms It can only be sea erosion landforms.

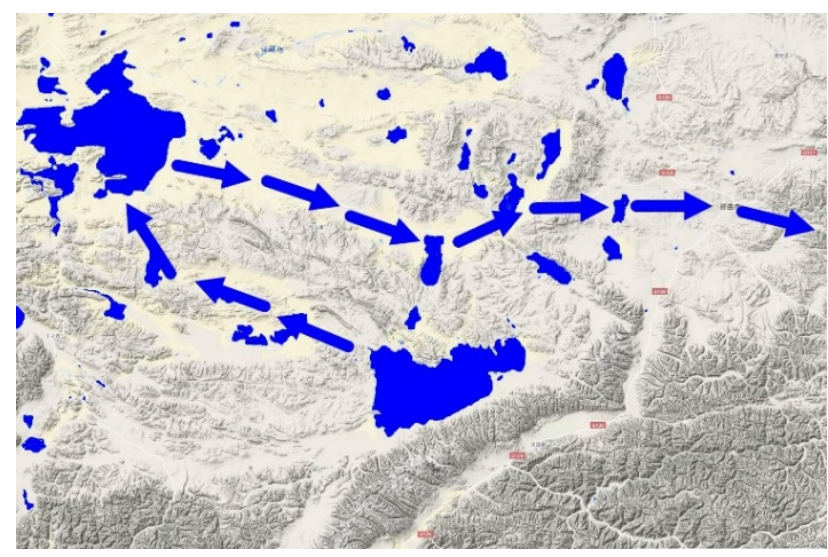

Figure 15 Schematic diagram of the waterway leading to the open sea during the existence of the ancient lagoon of Namtso.

\section{Namtso Ancient Sea Surface}

Since the earth's land and sea have been divided, the location of the earth's water surface has been in a cycle of changing - relatively stable - changing. It is neither static nor ever-changing. Judging from the author's mastery of ancient sea erosion landform research, among the locations of ancient sea surface discovered so far, the time that the sea surface remains between 4746 meters and 4755 meters in the current sea is relatively long. Annual plan.

In order to facilitate earth science research, it is necessary to name the sea surface that has existed at a certain location for a long time. First, it is convenient to name, second, it is convenient for comparison worldwide, and third, it is convenient for other earth science research. Based on the above considerations, and expressing the author's respect to the Tibetan people, the author named the sea surface that existed during the formation of the Namtso ancient sea erosion landform as "Namcuo ancient sea surface".

The altitude of 4746 meters to 4755 meters is very low in the northern Tibetan plateau, but in other continents, there are few areas that can reach this altitude. Mount Kilimanjaro, the highest peak in Africa, is Conghulu, 5895 meters above sea level; the highest mountain in Oceania, Jaya Peak, is 5030 meters above sea level; the highest peak in Western Europe, Mont Blanc, is only 4810 meters above sea level, on the surface of the Namtso ancient sea, Only 50 meters of exposure.

Fortunately, there are areas above the Namtso ancient sea surface on all continents, so we can find the sea erosion landforms generated during the existence of the Namtso ancient sea surface in these areas. These ancient sea erosion landforms in turn can confirm that the Namtso ancient sea surface is indeed Once existed.

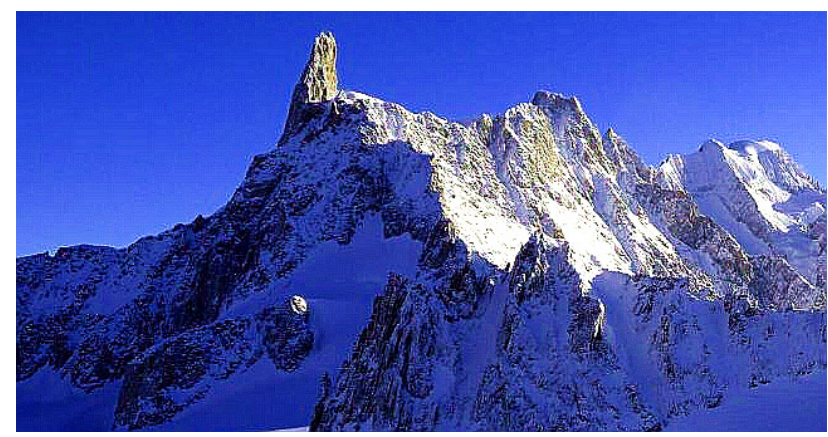

Figure 16 Mont Blanc, the highest peak in Western Europe. Mont Blanc is 4810 meters above sea level, and on the surface of Namtso ancient water, only a sea erosion column on the top of the mountain is exposed

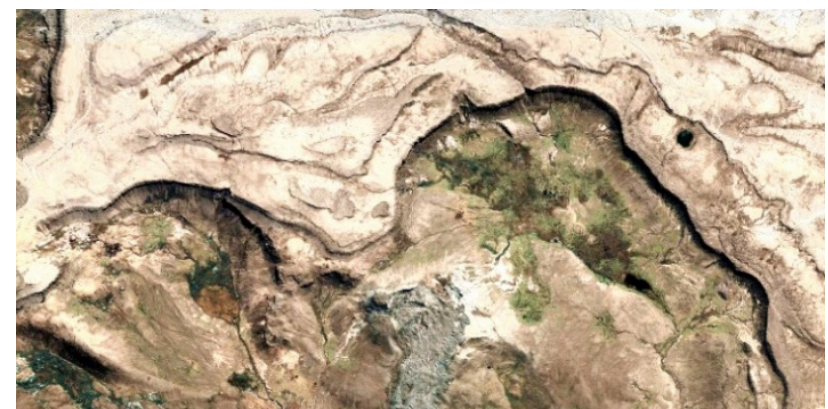

Figure 17 An ancient sea erosion cliff, ancient sea headland and ancient sea erosion headland at an altitude of 4746-4755 meters in South America 


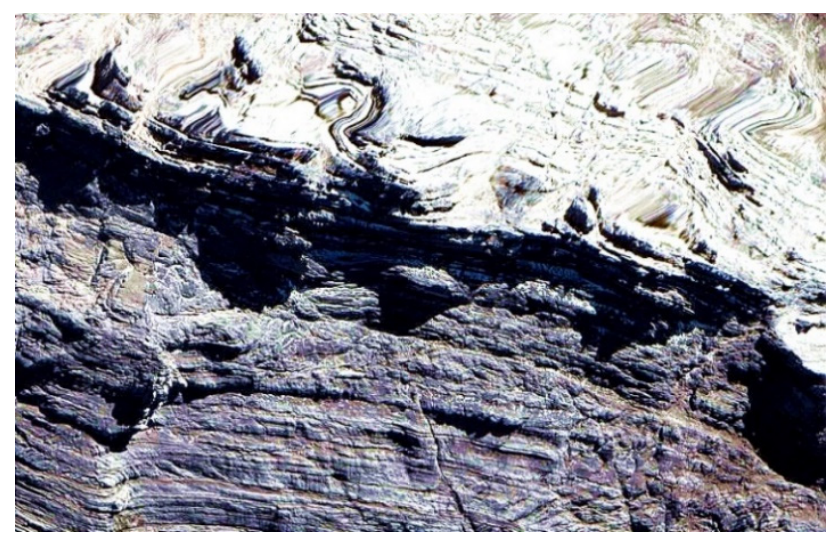

Figure 18Ancient sea erosion cliffs and ancient sea erosion cape bays at the curren altitude of 4746-4755 meters near the Chaya Peak, the highest peak in Oceania. Above this ancient sea cliff, it is the only island in Oceania that is over 300 meters

high and exposed on the surface of Namtso Ancient Sea

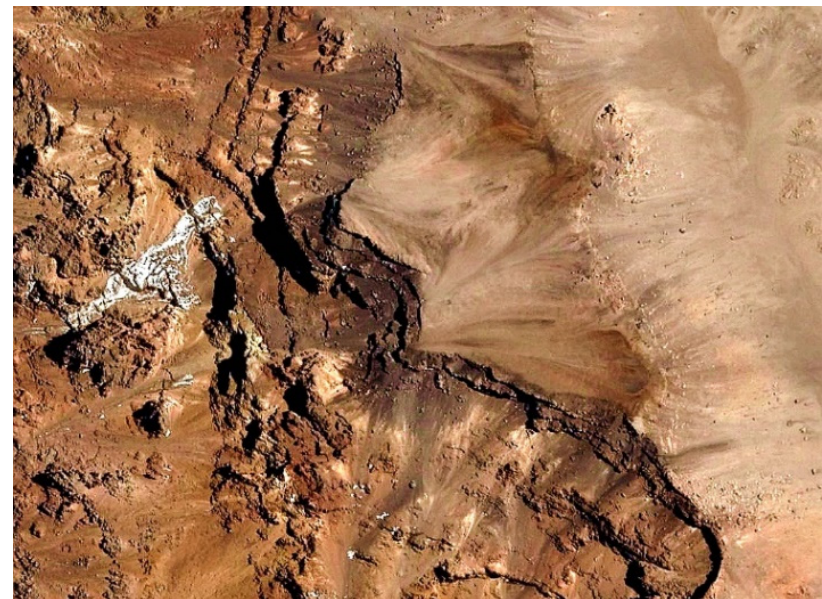

Figure 19.An ancient ancient sea erosion, ancient sea headland and ancient sea erosion headland at an altitude of 4746-4755 meters in the Kilimanjaro region, the highest peak in Africa

The ancient sea surface of Namco is also the highest ancient sea surface that can be compared on a global scale. There is also a remnant of ancient coastline on the highest mountain Everest in the world-ancient sea erosion cliffs and ancient sea erosion platforms, but other continents in the world do not have such a high altitude place to compare.

Above the Gangdese Mountains, which stretch for more than 1,200 kilometers, there are also three deep sea surface imprints. Similarly, no other continent in the world has such a high altitude.

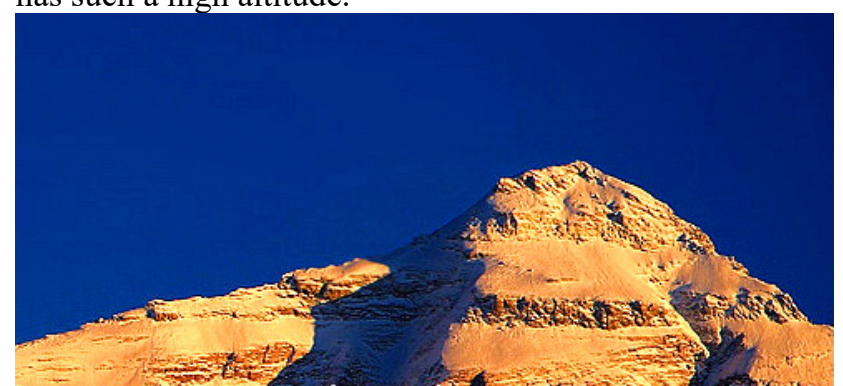

Figure 20 Everest, the highest peak in the world. At the top of Mount Everest, there is also the world's highest and unparalleled ancient sea erosion cliff and ancient sea erosion platform

\section{Conclusion:}

The ancient lagoon and ancient sea erosion landforms of Namtso provide concrete examples of land and sea borders during the period of geogeological history. Following the same method, we can find out the sea surface that has existed for a long time in the history of the earth, so as to better understand the history of the growth of the earth. The existence of the ancient sea surface in Namtso has also challenged the theory of continental drift and plate kinematics. These doctrines need to explain why the sea erosion landforms that occurred on a horizontal plane from tens of millions to hundreds of millions of years ago are still on the same level and have a relatively stable position relationship.

\section{References}

1. Edited by Wang Yonghong. Coastal Dynamic Geomorphology [M]. Beijing: Science Press, 2012.

2. Li Yaohuang. The annual rings of the mountain that grew up in the ocean [M]. Tianjin: Tianjin Education Press, 2014.5

3. Li Yaohuang. Exploring the ancient coast [M]. Chengdu: Sichuan University Press, 2018.6

4. Li Yaohuang. Uncovering the mystery of the dinosaur extinction [M]. Kunming: Yunnan Science and Technology Press, 2019.12 